\title{
Pengaruh Kadar C-Reactive Protein Serum Preoperatif terhadap Maturasi Fistula Radiosefalika
}

Dionisius Panji Wijanarkoํㅜ, Teguh Marfen Djajakusumah ${ }^{2}$, Putie Hapsari², Rama Nusjirwan ${ }^{3}$

${ }^{1}$ Departemen Bedah, Universitas Padjadjaran, Bandung

${ }^{2}$ Divisi Bedah Vaskular dan Endovaskular, Departemen Bedah, Universitas Padjadjaran, Bandung.

${ }^{3}$ Divisi Bedah Thoraks Kardio-Vaskular, Departemen Bedah, Universitas Padjadjaran, Bandung

\begin{abstract}
Abstrak
Latar Belakang. Penyakit ginjal kronis merupakan masalah kesehatan masyarakat global dengan prevalensi dan insidensi Gagal Ginjal Terminal (GGT) yang meningkat. Riset Kesehatan Dasar Indonesia menyatakan perawatan penyakit ginjal menjadi beban kedua tertinggi pembiayaan BPJS. Penganti fungsi ginjal yang umum dilakukan adalah hemodialisis (HD) sehingga akses vaskular menjadi hal penting dalam penanganan GGT. Fistula arteriovena (AVF) radiosefalika merupakan pilihan akses HD yang utama. Respon endotel merupakan aspek penting dari remodeling pembuluh darah yang diperlukan untuk keberhasilan AVF. CReactive Protein (CRP) yang bersirkulasi tinggi dapat menyebabkan disfungsi endotel sehingga diduga memiliki nilai prediksi terhadap maturasi AVF.

Metode. Desain analitik menggunakan metode kohort prospektif dengan consecutive sampling untuk menilai bagaimana pengaruh kadar CRP serum preoperatif terhadap maturasi AVF. Sampel diambil dari pasien GGT yang datang ke poliklinik Bedah RSUP Hasan Sadikin dan RSKG Ny.R.A.Habibie Bandung yang akan menjalani operasi AVF radiosefalika. Tes statistik menggunakan uji univariat untuk dekskripsi data. Perbedaan kadar CRP serum preoperatif berdasarkan perbedaan status maturasi AVF dianalisis melalui perbandingan kadar CRP serum preoperatif antar kelompok maturasi AVF melalui model bivariat uji t independen. Selanjutnya analisis untuk menguji hipotesis melalui analisis regresi logistik dengan batas kemaknaan 0,05. Hasil. Didapatkan 24 pasien (12 laki-laki, 12 perempuan) yang dilakukan analisis dengan rerata usia $45( \pm 16)$ tahun, rerata tekanan sistolik 149,2 $( \pm 28,4) \mathrm{mmHg}$. Didapatkan kadar CRP serum preoperatif berpengaruh negatif secara signifikan terhadap maturasi AVF dengan
\end{abstract}




\section{ARTIKEL PENELITIAN}

probabilitas kesalahan statistik sebesar $\mathrm{p}=0,0285(<0,05)$ dengan koefisien determinasi Nagelkerke (Nagelkerke R Squared) sebesar 71,1\%. Derajat kuatnya pengaruh kadar CRP serum preoperatif terhadap maturasi AVF tergolong kuat/tinggi berdasarkan klasifikasi Guilford yaitu $0,843(0,70-0,90)$.

Kesimpulan. Terdapat pengaruh kadar CRP serum preoperatif terhadap maturasi fistula radiosefalika. Semakin tinggi kadar CRP serum preoperatif, semakin rendah probabilitas maturasi fistula radiosefalika.

Kata Kunci. CRP, Fistula radiosefalika, prediktor.

(ISSN 2723-7494 J Bedah Indonesia. 2020;48:70-89)

Korespondensi penulis:

Dionisius Panji Wijanarko

Departemen Bedah, Universitas Padjadjaran, Bandung

Jalan Pasteur no. 38, Pasteur, Sukajadi, Bandung

Email : dionisius.p.w@gmail.com 


\title{
Effect of Preoperative Serum C-Reactive Protein Levels on the Maturation of Radiocephalic Fistulas
}

Dionisius Panji Wijanarkoํㅜ, Teguh Marfen Djajakusumah ${ }^{2}$, Putie Hapsari², Rama Nusjirwan ${ }^{3}$

\author{
${ }^{1}$ Surgery Department, Universitas Padjadjaran, Bandung \\ ${ }^{2}$ Division of Vascular and Endovascular, Surgery Department, Universitas Padjadjaran, \\ Bandung \\ ${ }^{3}$ Divison of Thorax Cardiovascular Surgery, Surgery Department, Universitas Padjadjaran, \\ Bandung
}

\begin{abstract}
Background. Chronic kidney disease is a global health problem with an increased incidence of End State renal Disease (ESRD). Indonesian health research states that the treatment of kidney disease is the second highest burden of health goverment financing. Hemodialysis is the most common kidney replacement therapy, which requires vascular access as an important tool in dealing with ESRD patient. Radiochepalic Arteriovenous fistula (AVF) is the main vascular access option. Endothelial response is an important aspect of vascular remodeling needed for the success of AVF maturation. High circulating C-Reactive Protein (CRP) can cause endothelial dysfunction therefore thought to have a predictive value for AVF maturation. Method. Prospective cohort analytical study with consecutive sampling were performed to evaluate the influence of preoperative serum CRP in ESRD patients who come to surgery outpatient departement at Dr. Hasan Sadikin Bandung hospital and Ny.RA Habibie hospital who will undergo radiocephalic fistula surgery. Univariate test for desciptive analisis. The difference of preoperative serum CRP levels in AVF maturation status were analyzed through bivariate independent t-test. Hipothetical analysis were done through logistic regression model with significance of 0.05 .
\end{abstract}

Results. There were 24 patients (12 male, 12 female) with a mean age of $45( \pm 16)$ years old and systolic blood pressure of 149.2( \pm 28.4$) \mathrm{mmHg}$. Preoperative CRP serum levels had negative effect significant to AVF maturation ( $p=0.0285)$ with Nagelkerke R Squared of $71.1 \%$. The degree of influence of preoperative serum CRP levels on AVF maturation is classified as strong based on Guilford's classification of 0.843(0.70-0.90). 


\section{ARTIKEL PENELITIAN}

Conclusion. Preoperative serum CRP levels had an effect on the maturation of radiosefalic fistulas. The higher the serum CRP level, the lower the probability of maturation.

Key words. CRP, Radiocephalic fistula, Predictor. 


\section{ARTIKEL PENELITIAN}

\section{Latar Belakang}

Gagal Ginjal Terminal (GGT) merupakan kondisi gagal ginjal kronis yang bersifat ireversibel. ${ }^{1,2}$ Penderita GGT membutuhkan pengganti fungsi ginjal yang harus dilakukan seumur hidup, terapi yang paling sering dilakukan adalah hemodialisis. $^{3} \quad$ Hemodialisis merupakan prosedur untuk menggantikan fungsi ekskretorik, fungsi homeostasis air dan elektrolit dari ginjal. ${ }^{4}$

Penyakit ginjal kronis (PGK) merupakan masalah kesehatan masyarakat global dengan prevalensi dan insidensi GGT yang meningkat, prognosis yang buruk dan biaya yang tinggi. Sekitar 1 dari 10 populasi global mengalami PGK. ${ }^{5}$ Hasil metaanalisis tahun 2016 oleh Hill dkk menyatakan prevalensi global PGK sebesar 13,4\%. ${ }^{2}$ Riset Kesehatan Dasar Indonesia menyatakan perawatan penyakit ginjal merupakan peringkat kedua pembiayaan terbesar dari BPJS kesehatan. Berdasarkan Indonesian Renal Registry (IRR) 2016 jumlah pasien PGK baru terus meningkat setiap tahun. ${ }^{6,7}$
Provinsi Jawa Barat tahun 2015 memiliki jumlah pasien PGK terbesar di Indonesia, yaitu 6305 jiwa dengan tindakan HD rutin terbesar, dilaporkan oleh 84 unit HD dengan insidensi penyulit pada saat HD kedua terbesar adalah masalah akses vaskular. ${ }^{7}$ IRR menunjukan bahwa jumlah proporsi tindakan HD dengan pemakaian kecepatan aliran darah (Qb) $<150 \mathrm{~mL} /$ menit di Jawa Barat merupakan yang terbesar. ${ }^{7}$ Melihat angka tersebut tidak mengherankan bahwa akses vaskular untuk hemodialisis merupakan hal yang layak diperhatikan sebagai seorang ahli bedah. ${ }^{7}$

The National Kidney Foundation/ Kidney Disease Outcomes Quality Initiative (NKF/KDOQI) merekomendasikan Arteriovenous fistula (AVF) menjadi pilihan utama sebagai akses vaskular pada pasien yang menjalani HD dan radiosefalika menjadi pilihan lokasi pertama saat operasi pembuatan AVF. ${ }^{8,9}$ NKF/KDOQI menyatakan AVF dikatakan matur bila pembuluh darah tersebut menghasilkan aliran darah lebih $600 \mathrm{~mL} / \mathrm{menit}$, memiliki diameter lebih besar dari $6 \mathrm{~mm}$ dan 


\section{ARTIKEL PENELITIAN}

berjarak sekitar $6 \mathrm{~mm}$ dari permukaan kulit. ${ }^{11-15}$ Khavanin Zadeh M dkk ${ }^{16}$ mengatakan bahwa secara klinis, kegagalan awal telah didefinisikan sebagai AVF yang tidak pernah berkembang secara memadai untuk dialisis (kegagalan untuk matur), atau yang gagal dalam satu bulan memulai dialisis. $^{16}$ Kegagalan AVF memberikan dampak yang serius bagi pasien antaralain meningkatkan morbiditas dan biaya karena harus dilakukan operasi berulang, karena itu penting untuk dilakukan identifikasi prediktor preoperatif keberhasilan AVF untuk mengurangi angka kegagalan operasi. 9,10 Saat ini diperkirakan bahwa antara 23-46\% dari semua AVF (Eropa dan Amerika Serikat) memiliki masalah dengan kegagalan maturasi yang menyebabkan patensi akses pembuluh darah selama 1 tahun hanya sebesar $60 \%-65 \% .{ }^{17}$ Dember melaporkan bahwa tingkat nonmaturasi akses autogenus di Amerika Serikat adalah 62\% pada uji coba Dialisis Access Consortium (DAC), sebuah percobaan multisenter oleh National Institutes of Health (NIH). ${ }^{18}$
Faktor yang berperan dalam keberhasilan patensi AVF dapat berupa kondisi sistemik yaitu demografis (usia, jenis kelamin, etnik), penyakit yang diderita sebelumnya (arteriosklerosis, aterosklerosis, penyakit jantung, diabetes melitus), respon endotelial, thrombofilia, ataupun kondisi lokal yaitu teknik operasi, kualitas dan laju aliran pembuluh darah. ${ }^{9}, 16$ Respon endotelium merupakan aspek penting dari remodeling pembuluh darah yang diperlukan untuk maturasi AVF. Endotelium bertindak sebagai penghubung antara darah dan jaringan lain di dalam tubuh yang berperan penting dalam menjaga lingkungan vaskular melalui pelepasan agen yang mengatur respon vasomotor, respon inflamasi dan fungsi homeostatik. Hilangnya respon vasodilatasi, pembentukan trombosis, pembengkakan dan proliferasi seluler yang terkait dengan disfungsi endotel merupakan topik penelitian yang berpotensi, karena mekanisme ini terkait erat dengan maturasi AVF. 16,19 Pemeriksaan biomarker seperti $C$ Reactive Protein (CRP) relatif tersedia dan terjangkau, memiliki 


\section{ARTIKEL PENELITIAN}

nilai prediksi terhadap prognosis pasien GGT, dan tidak tergantung pada operator namun belum banyak penelitian yang cukup untuk membuktikan kegunaannya terhadap akses vaskular. ${ }^{9}$

C-Reactive Protein adalah protein plasma filogenetik yang berpartisipasi dalam respons sistemik terhadap inflamasi. ${ }^{20}$ C-Reactive Protein dapat mengacaukan kerja mRNA Nitrat Oksida (nitric oxide syntase mRNA) dalam sel endotel yang berfungsi untuk respon vasomotor sehingga CRP yang bersirkulasi tinggi dapat menyebabkan disfungsi endotel. ${ }^{9,16,19}$ Kadar CRP serum preoperatif pada pasien dengan GGT diduga memiliki pengaruh terhadap maturasi AVF.

\section{Metode}

Penelitian ini merupakan suatu penelitian kohort prospektif dengan consecutive sampling. Populasi target adalah semua pasien gagal ginjal terminal yang datang berobat ke RSUP Dr. Hasan Sadikin Bandung dan RSKG R.A.Habibie, mencakup semua usia, baik laki-laki maupun perempuan. Populasi terjangkau, adalah pasien GGT yang datang ke poliklinik Bedah RSUP Dr. Hasan Sadikin Bandung dan RSKG Ny.R.A.Habibie yang akan menjalani operasi AVF radiosefalika dari tanggal 1 Oktober 2018 sampai dengan 28 Februari 2019. Sampel adalah sebagian populasi terjangkau yang setuju dilibatkan dalam penelitian.

Penelitian ini dilakukan untuk mengetahui pengaruh CRP serum preoperatif terhadap maturasi fistula radiosefalika. Tes statistik menggunakan uji univariat untuk dekskripsi data. Perbedaan kadar CRP serum preoperatif berdasarkan perbedaan status maturasi AVF dianalisis melalui perbandingan kadar CRP serum preoperatif antar kelompok maturasi AVF melalui model bivariat uji $t$ independen. Selanjutnya analisis untuk menguji hipotesis melalui analisis regresi logistik dengan batas kemaknaan 0,05 .

Fistula arteriovena dikatakan matur bila pembuluh darah tersebut menghasilkan aliran darah lebih $600 \mathrm{~mL} / \mathrm{menit}$ memiliki diameter lebih besar dari $6 \mathrm{~mm}$ dan berjarak 


\section{ARTIKEL PENELITIAN}

kurang dari $6 \mathrm{~mm}$ dari permukaan kulit

\section{Hasil}

Selama periode 1 Oktober 2018 28 Februari 2019 didapatkan 24 pasien GGT yang akan menjalani operasi AVF pertama. Tidak ada pasien yang terekslusi atau drop out sehingga seluruhnya dilibatkan dalam penelitian.

Hasil pemeriksaan menunjukkan bahwa mayoritas AVF berhasil matur, yaitu sebanyak 16 pasien $(66,7 \%)$ dengan rerata laju aliran darah vena sefalika pasca operasi adalah 567,9 $\pm 118,9 \mathrm{~mL} / \mathrm{menit}$. Pasien yang matur memiliki rerata laju aliran darah vena sefalika yang lebih tinggi (636,9 $\pm 19,9 \mathrm{~mL} / \mathrm{menit}$ ) daripada pasien yang non matur $(430,0 \pm 113,9$ $\mathrm{mL} / \mathrm{menit})$. Rerata diameter vena sefalika pasien adalah sebesar 5,6 \pm 1,2 mm. Pasien yang matur memiliki rerata diameter vena sefalika yang lebih tinggi $(6,3 \pm 0,2 \mathrm{~mm})$ daripada pasien yang non matur $(4,2 \pm 1,1 \mathrm{~mm})$. Rerata kedalaman vena sefalika pasien adalah 5,6 $\pm 0,5 \mathrm{~mm}$. Pasien yang matur memiliki rerata kedalaman vena sefalika yang lebih rendah $(5,5 \pm 0,3 \mathrm{~mm})$ daripada pasien yang non matur $(5,7 \pm 0,8$ $\mathrm{mm})$.

Sebagian pasien berjenis kelamin laki-laki (12 pasien, 50,0\% dari sampel), dan sebagian pasien lainnya perempuan. Pasien yang matur didominasi pasien laki-laki sebanyak 9 pasien $(56,3 \%$ dari total pasien yang matur). Pasien yang non matur didominasi pasien perempuan, yaitu sebanyak 5 pasien $(62,5 \%$ dari total pasien yang non matur).

Rerata usia pasien adalah 45,0 \pm 16,0 tahun dengan rentang usia antara 21 - 76 tahun. Pasien yang matur memiliki rerata usia yang lebih tinggi (47,9 $\pm 16,5$ tahun) daripada pasien yang non matur $(39,0 \pm 14,2$ tahun). Sedangkan rerata tekanan darah sistolik memiliki median $155 \mathrm{mmHg}$ dan rentang tekanan darah sistolik antara 100- 200mmHg. Pasien yang matur memiliki rerata tekanan darah sistolik yang lebih tinggi (151,9 \pm $26,4 \mathrm{mmHg}$ ) daripada pasien yang non matur $(143,8 \pm 33,4 \mathrm{mmHg})$.

Berdasarkan Uji Korelasi Pearson, variabel yang memiliki hubungan dengan maturasi adalah kadar serum CRP preoperatif, sedangkan usia, 


\section{ARTIKEL PENELITIAN}

jenis kelamin, diameter vena, dan diameter arteri tidak signifikan berhubungan dengan maturitas AVF.

Hasil uji normalitas menggunakan uji Shapiro-Wilk menunjukkan bahwa distribusi data kadar CRP serum preoperatif terdistribusi normal ( $p>0,05)$, baik pada kelompok AVF yang matur $(p=0,709)$ maupun non matur $\quad(p=0,062), \quad$ sehingga perbandingan kadar CRP serum preoperatif berdasarkan maturasi AVF dilakukan dengan uji $t$ independen.

Pada tabel 1 didapatkan rerata kadar CRP serum preoperatif pasien adalah $1,507 \pm 1,563 \mathrm{mg} / \mathrm{dL}$, kelompok AVF yang matur memiliki rerata kadar CRP serum preoperatif $0,716 \pm 0,474 \mathrm{mg} / \mathrm{dL}$ lebih rendah dibandingkan dengan kelompok non matur yaitu 3,091 $\pm 1,802 \mathrm{mg} / \mathrm{dL}$.

Pada tabel 2 didapatkan hasil uji $\mathrm{t}$ independen membuktikan bahwa ada perbedaan kadar CRP serum preoperatif yang signifikan antara kelompok AVF yang matur dengan kelompok non matur $(p=0,007)$. Oleh karena itu penelitian dapat dilanjutkan dengan analisis pengaruh kadar CRP serum preoperatif terhadap maturasi AVF.

Pengaruh Kadar CRP Serum Preoperatif terhadap Maturasi AVF diuji berdasarkan hasil analisis regresi logistik bivariat.

Hasil uji Wald membuktikan bahwa kadar CRP serum preoperatif berpengaruh secara signifikan dengan $p=0,0285(p<0,05)$ dalam uji regresi logistik bivariat. Koefisien regresi dari CRP bernilai negatif (-2.873). Hasil ini menunjukkan bahwa semakin tinggi kadar CRP serum preoperatif, semakin rendah probabilitas AVF untuk matur. Besarnya pengaruh kadar CRP serum preoperatif terhadap maturasi $\mathrm{AVF}$ ditunjukkan oleh koefisien determinasi Nagelkerke (Nagelkerke $R$ Squared) sebesar 0,711 atau 71,1\%. Derajat kuatnya pengaruh kadar CRP serum preoperatif terhadap maturasi AVF tergolong kuat/tinggi, sebagaimana ditunjukkan oleh akar dari Nagelkerke $R$ Squared $\left(\sqrt{ } \mathrm{r}^{2}\right)=$ 0,843 yang terletak dalam rentang kategori kuat/tinggi menurut klasifikasi Guilford, yaitu: antara 0,70 $-0,90$. 


\section{ARTIKEL PENELITIAN}

\section{Pembahasan}

Fistula arteriovena yang dibuat melalui pembedahan adalah bentuk pilihan akses vaskular jangka panjang untuk digunakan dalam terapi hemodialisis. Statistik terbaru di USA menunjukkan bahwa pada tahun 2015 $66 \%$ pasien HD rutin menggunakan AVF untuk akses vaskular, dan proporsi ini diperkirakan akan meningkat sejalan dengan inisiatif nasional 'Fistula First Catheter Last'. ${ }^{27}$

Pada penelitian ini terdapat 24 pasien GGT yang dirujuk ke divisi bedah dan memenuhi kriteria inklusi kemudian dilakukan operasi fistula radiosefalika. Jumlah yang terbilang sedikit dibandingkan dengan jumlah pasien yang menjalani HD selama 3 bulan menggambarkan bahwa kemungkinan masih kurang kesadaran masyarakat di Indonesia yang segera menjalani operasi AVF setelah didiagnosis menderita GGT. Jumlah ini juga tergolong sedikit dibandingkan dengan jumlah pasien yang dilakukan operasi selama masa penelitian, hal ini menggambarkan besarnya jumlah pasien yang menjalani operasi perbaikan AVF atau dengan kata lain besarnya kegagalan operasi pertama dan besarnya jumlah pasien AVF yang menderita diabetes melitus, sebagaimana telah diketahui DM diduga juga memiliki pengaruh dalam kegagalan maturasi AVF. ${ }^{25}$

Pada tabel 4.1 diperoleh data bahwa pasien laki-laki dan perempuan sama banyak masing masing 12(50\%). Pada pasien lakilaki, dari 12 subjek penelitian diperoleh sebanyak 9 AVF yang berhasil matur sedangkan 3 tidak berhasil. Pada pasien perempuan, dari 12 subjek penelitian diperoleh sebanyak 7 AVF yang berhasil matur sedangkan 5 pasien tidak berhasil. Hasil ini memberikan informasi bahwa operasi pembuatan AVF banyak yang berhasil pada pasien laki-laki, hal ini sesuai dengan penelitian sebelumnya yang menyatakan bahwa jenis kelamin merupakan salah satu faktor yang mempengaruhi keberhasilan AVF, namun faktor ini merupakan suatu kondisi yang tidak dapat dimodifikasi. ${ }^{16}$

Pada penelitian ini pasien subjek penelitian memiliki karakteristik 


\section{ARTIKEL PENELITIAN}

rerata usia $44,96( \pm 16,03)$, secara umum lebih muda dibandingkan dengan subjek penelitian di negara barat (rerata 57, range 45-68 tahun). ${ }^{27}$ Pada penelitian yang dilakukan oleh Miller dkk usia diduga memiliki korelasi negatif terhadap maturasi AVF. ${ }^{25}$ Namun pada metaanalisis yang dilakukan oleh M.A.Siddiqui dkk dikatakan bahwa beberapa peneliti mendapatkan usia tidak berhubungan secara langsung dengan maturasi AVF. ${ }^{34}$ Pada penelitian ini rerata usia pasien yang matur $(47,9 \pm 16,5$ tahun) lebih tua dibandingkan dengan yang tidak matur (39,0 $\pm 14,2$ tahun).

Pasien yang berhasil mencapai maturasi pada penelitian ini sebesar 66,6\% ( 16 dari 24 subjek penelitian), tidak ada data yang menunjukkan jumlah keberhasilan AVF di Indonesia namun angka ini serupa dibandingkan dengan angka keberhasilan pada penelitian sebelumnya yang menyatakan bahwa diperkirakan 23-46\% dari semua AVF (Eropa dan Amerika Serikat) memiliki masalah dengan kegagalan maturasi yang menyebabkan patensi akses pembuluh darah selama 1 tahun hanya sebesar $60-65 \%{ }^{17}$ Meskipun demikian pada 8 subjek yang tidak masuk dalam kriteria matur berdasarkan penelitian ini, terdapat 3 pasien yang tetap dapat dilakukan HD menggunakan akses AVF yang telah dibuat. Perbedaan kriteria maturitas yang digunakan dapat menjelaskan perbedaan angka keberhasilan dari AVF yang dibuat, meskipun demikian yang menjadi masalah utama adalah tetap besarnya angka kegagalan maturasi AVF sehingga perlu dilakukan evaluasi terhadap faktorfaktor yang mempengaruhi dalam keberhasilan AVF. Meskipun telah dianjurkan dalam guideline NKF/KDOQI, kurangnya monitor evaluasi rutin pasca operasi di Indonesia menjadi salah satu kendala besar dalam perkembangan penelitian yang ada. Terdapat kendala akses fasilitas kesehatan yang mampu melakukan kontrol pasca AVF membuat beberapa pasien tidak dianjurkan kontrol setelah akses vaskular tersebut dapat digunakan untuk HD oleh tenaga medis setempat.

Pada seluruh sampel yang diambil tidak terdapat komplikasi infeksi 


\section{ARTIKEL PENELITIAN}

pasca operasi yang dapat menjadi kriteria drop out pada penelitian ini, hal ini memberikan informasi bahwa perawatan luka pasca operasi sudah cukup baik.

Penelitian ini difokuskan pada pengaruh biomarker inflamasi yaitu CRP serum terhadap keberhasilan maturasi AVF, didapatkan hasil bahwa derajat pengaruh kadar CRP serum preoperatif terhadap maturasi fistula radiosefalika tergolong kuat berdasarkan klasifikasi Guillford. $C$ Reactive Protein dapat mengacaukan mRNA nitrat oksida dalam sel endotel sehingga menyebabkan disfungsi endotel. ${ }^{9,16,19}$. Berdasarkan kajian literatur mekanisme utama penyebab kegagalan fistula adalah perubahan regangan gesek dinding pembuluh darah dan tekanan transmural/sirkumferensial.

Perubahan gesekan dinding pembuluh darah (wall shear stress) akan mengakibatkan hiperplasia neointimal AVF, sedangkan peningkatan tekanan transmural akan menyebabkan medial hipertropi. ${ }^{17,29}$ Disfungsi endotel yang disebabkan oleh proses inflamasi dapat mengganggu respon vaskular terhadap friksi dinding pembuluh yang meningkat, sehingga menghambat dilatasi dan peningkatan laju aliran yang diperlukan untuk pematangan AVF. ${ }^{9}$

Metanalisis yang dilakukan Susan K.Morton dkk mengatakan bahwa mayoritas kegagalan AVF selama proses maturasi terjadi karena komplikasi stenosis vena dan trombosis pada populasi pasien yang menjalani HD. ${ }^{27}$ Pada penelitian ini didapatkan 4 pasien yang memliki diameter vena yang kecil pada satu bulan pasca operasi AVF dan 3 pasien yang ditemukan trombosis pada $5 \mathrm{~cm}$ distal dari lokasi AVF. Berdasarkan uraian diatas kejadian stenosis dan trombosis berkaitan erat dengan proses inflamasi. Hal ini memperkuat dugaan bahwa faktor inflamasi berpengaruh kuat dalam proses maturasi AVF. Hasil tersebut konsisten dengan hasil penelitianpenelitian sebelumnya. RoyChaudhury pada tahun 1996 merupakan orang pertama yang menemukan peran peradangan pada kegagalan AVF. Studinya menunjukkan hiperplasia intimal agresif dalam pembuluh anastomosis 


\section{ARTIKEL PENELITIAN}

terkait dengan oklusi trombotik AVF, yang mengakibatkan kegagalan AVF. ${ }^{16}$ Kaygin MA dkk pada tahun 2013 mengatakan tingkat CRP serum ditemukan tinggi pada $25,7 \%$ kasus AVF yang berhasil dan 69,3\% kasus AVF yang tidak berhasil, menunjukan korelasi positif antara CRP serum dan AVF yang tidak berhasil dalam penelitian ini. ${ }^{19}$ Demikian pula penelitian yang dilakukan oleh Khavanin Zadeh dan Rhasid Usman yang mengatakan bahwa tingkat CRP yang meningkat terkait dengan tingkat kegagalan maturasi AVF. Oleh karena itu, disarankan untuk memeriksa kadar CRP sebelum operasi untuk mengidentifikasi pasien yang berisiko lebih tinggi mengalami kegagalan fistula. ${ }^{35}$

Ditemukan juga bahwa koefisien regresi bernilai minus $(-2,873)$ dengan demikian dapat dikatakan bahwa pengaruh kadar CRP serum berbanding terbalik terhadap maturasi AVF dengan $r^{2}$ sebesar $71,1 \%$ yang menunjukan besarnya pengaruh, sedangkan sisanya $\quad(29,9 \%)$ merupakan faktor-faktor yang tidak diikutsertakan dalam analisis penelitian ini. Faktor-faktor yang diduga memiliki pengaruh antara lain kecepatan aliran dari arteri, kemampuan dilatasi vena, penyakit penyerta seperti penyakit jantung koroner, penyakit vaskular perifer, dislipidemia, dan kelainan koagulasi. ${ }^{16,34}$

Keterbatasan dalam penelitian ini antara lain adalah tidak memasukan faktor masalah intraoperasi (technical error), tidak menganalisis penyebab peningkatan CRP pada subjek, kurangnya homogenitas perlakuan sampel selama massa follow up, faktor yang dapat mengganggu maturasi AVF setelah menjalani operasi seperti aktifitas fisik, penekanan pada vena sefalika, latihan tangan, serta penyakit yang seperti penyakit jantung koroner dan stroke dapat berpengaruh dalam proses maturasi AVF. Pada penelitian ini juga membatasi populasi pada pasien yang menjalani AVF pertama di radiosefalika dan juga mengeksklusi penyakit-penyakit penyerta seperti diabetes mellitus, atherosklerosis dan trombosis vena sehingga kurang menggambarkan pengaruh kadar CRP serum pada populasi sebenarnya. Peneliti juga tidak mengekslusikan 3 


\section{ARTIKEL PENELITIAN}

pasien yang telah dilakukan kanulasi dini pasca operasi, meskipun pada ketiga subjek tetap ditemukan AVF yang matur namun hal ini dapat menjadi penyebab AVF yang tidak bertahan lama.

\section{Kesimpulan}

Terdapat pengaruh kadar CRP serum preoperatif terhadap maturasi fistula radiosefalika. Semakin tinggi kadar CRP serum preoperatif, semakin rendah probabilitas maturasi fistula radiosefalika. Derajat pengaruh kadar CRP serum preoperatif terhadap maturasi fistula radiosefalika tergolong kuat.

\section{Saran}

Dari kesimpulan yang didapatkan maka disarankan untuk memeriksakan CRP sebelum melakukan operasi AVF. Untuk penelitian berikutnya disarankan menginklusikan faktor penyakit penyerta DM, penyakit jantung koroner, penyakit vaskular perifer, dislipidemia, kelainan koagulasi dan juga menginklusikan lokasi AVF lainnya termasuk pasien yang melakukan revisi AVF untuk mendapatkan gambaran populasi menyeluruh terhadap prediksi maturasi yang dapat digunakan terhadap semua pasien GGT yang akan menjalani operasi pembuatan AVF.

Untuk penilaian yang lebih baik dapat dilakukan perbandingan CRP dengan biomarker inflamasi lainnya seperti leukosit, hitung jenis leukosit, Absolut Neutrophil Count (ANC), Neutrofil-lymphosit Rasio (NLR), fibrinogen dan atau kombinasinya. Disarankan juga untuk menganalisis keuntungan pemeriksaan dan ketersediaannya. Pentingnya kontrol post operasi AVF harus ditekankan untuk kebaikan pasien dan perkembangan pengetahuan mengenai keberhasilan AVF di Indonesia. 


\section{Daftar Pustaka}

1. Agarwal R. Defining end-stage renal disease in clinical trials: a framework for adjudication. Nephrology Dialysis Transplantation. 2016;31(6):8647.

2. Rebecca M. Minter GMD. Vascular Access for Dialysis. In: Frank C. Vandy MPKH, MD, editor. Current Procedures: Surgery. United States of America: The McGraw-Hill Companies, Inc; 2010.

3. Fernandez-Fresnedo G, de Francisco A, Ruiz JC, Cotorruelo JG, Alamillo CG, Valero R, et al. Relevance of chronic kidney disease classification (K/DOQI) in renal transplant patients. Transplantation proceedings. 2006;38(8):2402-3.

4. Arthur C. Guyton JEH. Textbook of Medical Physiology. 11 ed: Elsevier Inc.; 2006.

5. Chronic Kidney Disease [Internet]. World Kidney Day. 2017. Available from:http://www.worldkidneyda y.org/faqs/chronic-kidneydisease/.

6. Prodjosudjadi W, Suhardjono A. End-stage renal disease in Indonesia: treatment development. Ethnicity \& disease. 2009;19(1 Suppl 1):S133-6.

7. Registry TIR. Situasi Penyakit Ginjal Kronis. In: RI KK, editor. Indonesia: Infodatin, Pusat Data dan Informasi Kementrian Kesehatan RI; 2017.
8. Jennings WC. Creating arteriovenous fistulas in 132 consecutive patients: exploiting the proximal radial artery arteriovenous fistula: reliable, safe, and simple forearm and upper arm hemodialysis access. Archives of surgery (Chicago, Ill : 1960). 2006;141(1):27-32; discussion

9. McGrogan DG, Maxwell AP, Khawaja AZ, Inston NG. Current tools for prediction of arteriovenous fistula outcomes. Clinical Kidney Journal. 2015;8(3):282-9.

10. Saucy F, Haesler E, Haller C, Deglise S, Teta D, Corpataux JM. Is intra-operative blood flow predictive for early failure of radiocephalic arteriovenous fistula? Nephrology, dialysis, transplantation : official publication of the European Dialysis and Transplant Association - European Renal Association. 2010;25(3):862-7.

11. Navuluri R, Regalado S. The KDOQI 2006 Vascular Access Update and Fistula First Program Synopsis. Seminars in Interventional Radiology. 2009;26(2):122-4.

12. Padberg FT, Jr., Calligaro KD, Sidawy AN. Complications of arteriovenous hemodialysis access: Recognition and management. Journal of vascular surgery.48(5):S55-S80.

13. Sidawy AN, Gray R, Besarab A, Henry M, Ascher E, Silva M, Jr., et al. Recommended standards for reports dealing with arteriovenous hemodialysis 


\section{ARTIKEL PENELITIAN}

accesses. Journal of vascular surgery. 2002;35(3):603-10.

14. Berman S. Vascular Access in Clinical Practice. Erdoes SL BS, editor. Arizona: Marcel Dekker, Inc.; 2002.

15. Yuwono H. Operasi Cimino. Ilmu Bedah Vaskular Sains dan Pengalaman Praktis. 1 ed. Bandung, Indonesia: Refika Aditama; 2010. p. 67-98.

16. Khavanin Zadeh M, Mohammadipour S, Omrani Z. Correlation between CRP and early failure of arteriovenous fistula (AVF). Medical journal of the Islamic Republic of Iran. 2015;29:219-.

17. Roy-Chaudhury P, Spergel LM, Besarab A, Asif A, Ravani P. Biology of arteriovenous fistula failure. Journal of nephrology. 2007;20(2):150-63.

18. Huber TS. Hemodialysis Access: General Considerations. In: Jack L. Cronenwett M, editor. RUTHERFORD'S VASCULAR SURGERY. 8th ed. Philadelphia: Saunders, an imprint of Elsevier Inc.; 2014.

19. Kaygin MA, Halici U, Aydin A, Dag O, Binici DN, Limandal HK, et al. The relationship between arteriovenous fistula success and inflammation. Renal Failure. 2013;35(8):1085-8.

20. Steven Black IK, and David Samols. C-Reavtive protein. Journal of Biological Chemistry. 2004.

21. Musa Wnalhtamanaki. Predictors for failure to mature of autogenous arteriovenous fistulae: Alor Setar experience. The Medical journal of Malaysia\},. 2012;67 2:165-8.
22. Greene N. Coppola, Cimino: The Operatics of History. Film Quarterly. 1984;38(2):28-37.

23. Galland B. Rutherford's Vascular Surgery, 7th edn. Annals of The Royal College of Surgeons of England. 2011;93(2):176-.

24. Hod T, Desilva RN, Patibandla BK, Vin Y, Brown RS, GoldfarbRumyantzev AS. Factors predicting failure of AV "fistula first" policy in the elderly. Hemodialysis international International Symposium on Home Hemodialysis. 2014;18(2):507-15.

25. Miller CD, Robbin ML, Allon M. Gender differences in outcomes of arteriovenous fistulas in hemodialysis patients. Kidney international. 2003;63(1):34652.

26. Ng YY, Wu SC, Hung YN, Ko PJ. Effect of demographic characteristics and timing of vascular access maturation on patency in Chinese incident haemodialysis patients. Nephrology, dialysis, transplantation : official publication of the European Dialysis and Transplant Association - European Renal Association. 2009;24(11):344753.

27. Morton SK, Rodríguez AJ, Morris DR, Bhandari AP, Moxon JV, Golledge J. A Systematic Review and Meta-Analysis of Circulating Biomarkers Associated with Failure of Arteriovenous Fistulae for Haemodialysis. PLOS ONE. 2016;11(7):e0159963.

28. Fan PY, Schwab SJ. Vascular access: concepts for the 1990s. Journal of the American Society 


\section{ARTIKEL PENELITIAN}

of Nephrology : JASN. 1992;3(1):1-11.

29. Zhihua Jiang CKO. Intimal Hyperplasia. In: Jack L. Cronenwett M, editor. RUTHERFORD'S VASCULAR SURGERY. 8th ed. Philadelphia: Saunders, an imprint of Elsevier Inc.; 2014.

30. Zarins CK, Giddens DP, Bharadvaj BK, Sottiurai VS, Mabon RF, Glagov S. Carotid bifurcation atherosclerosis. Quantitative correlation of plaque localization with flow velocity profiles and wall shear stress. Circulation research. 1983;53(4):502-14.

31. Speidl WS, Graf S, Hornykewycz S, Nikfardjam M, Niessner A, Zorn G, et al. Highsensitivity C-reactive protein in the prediction of coronary events in patients with premature coronary artery disease. American heart journal. 2002;144(3):449-55.

32. Victor W. Rodwell DAB, Kathleen M. Botham. Harper's : Illustrated Biochemistry. 30 ed. USA: The McGraw-Hill Education; 2015.
33. Pearson TA, Mensah GA, Alexander RW, Anderson JL, Cannon RO, 3rd, Criqui M, et al. Markers of inflammation and cardiovascular disease: application to clinical and public health practice: A statement for healthcare professionals from the Centers for Disease Control and Prevention and the American Heart Association. Circulation. 2003;107(3):499-511.

34. Siddiqui MA, Ashraff S, Carline $\mathrm{T}$. Maturation of arteriovenous fistula: Analysis of key factors. Kidney research and clinical practice. 2017;36(4):318-28.

35. Rashid Usman MJ, HanifAbbassi. Association between Raised Serum CReactive Protein and Arteriovenous Fistula Failure. Journal of Islamabad Medical \& Dental College (JIMDC). 2016:157-60.

Tabel 1 Subjek Penelitian

\begin{tabular}{lcccc}
\hline Variabel & Total & Non Matur & Matur & $\mathbf{p}^{*}$ \\
\hline & & & \\
jibiikabi.org & 86 & Jurnal Ilmu Bedah Indonesia
\end{tabular}




\section{ARTIKEL PENELITIAN}

\begin{tabular}{|c|c|c|c|c|}
\hline & $n=24(100 \%)$ & $n=8(33,3 \%)$ & $n=16(66,7 \%)$ & \\
\hline Jenis Kelamin & & & & 0,667 \\
\hline Laki-laki & $12(50 \%)$ & $3(37,5 \%)$ & $9(56,3 \%)$ & \\
\hline Perempuan & $12(50 \%)$ & $5(62,5 \%)$ & $7(43,8 \%)$ & \\
\hline Umur (tahun) & & & & 0,204 \\
\hline Mean $( \pm$ SD) & $45,0( \pm 16)$ & $39,0( \pm 14,2)$ & $47,9( \pm 16,5)$ & \\
\hline Median & 47 & 36 & 53,5 & \\
\hline Min-max & $21-76$ & $21-64$ & $24-76$ & \\
\hline $\begin{array}{l}\text { Tekanan sistolik } \\
(\mathrm{mmHg})\end{array}$ & & & & 0,521 \\
\hline Mean $( \pm$ SD $)$ & $149,2( \pm 28,4)$ & $143,8( \pm 33,4)$ & $151,9( \pm 26,4)$ & \\
\hline Median & 155 & 150 & 155 & \\
\hline Min-max & $100-200$ & $100-180$ & $100-200$ & \\
\hline $\begin{array}{l}\text { Diameter vena } \\
\text { preoperatif }(\mathrm{mm})\end{array}$ & & & & 0,088 \\
\hline Mean $( \pm \mathrm{SD})$ & $2,4(0,5)$ & $2,0(0)$ & $2,6(0,5)$ & \\
\hline Median & 2,25 & 2,0 & 2,5 & \\
\hline Min-max & $2,0-4,0$ & 2,0 & $2,0-4,0$ & \\
\hline $\begin{array}{l}\text { Diameter arteri } \\
\text { preoperatif }(\mathrm{mm})\end{array}$ & & & & 0,239 \\
\hline Mean $( \pm \mathrm{SD})$ & $2,1(0,24)$ & $2,0(0)$ & $2,0(0,3)$ & \\
\hline Median & 2,0 & 2,0 & 2,0 & \\
\hline Min-max & $2,0-3,0$ & 2,0 & $2,0-3,0$ & \\
\hline $\begin{array}{l}\text { CRP serum } \\
\text { preoperatif } \\
(\mathrm{mg} / \mathrm{dL})\end{array}$ & & & & 0,001 \\
\hline Mean $( \pm \mathrm{SD})$ & $1,507( \pm 1,563)$ & $3,091( \pm 1,802)$ & $0,716( \pm 0,474)$ & \\
\hline Median & 0,912 & 3,050 & 0,567 & \\
\hline Min-max & $0,143-6,030$ & $0,882-6,030$ & $0,143-1,587$ & \\
\hline $\begin{array}{l}\text { Laju aliran vena } \\
\text { pasca operasi } \\
(\mathrm{ml} / \mathrm{min})\end{array}$ & & & & \\
\hline Mean $( \pm$ SD $)$ & $567,9( \pm 118,9)$ & $430,0( \pm 113)$ & $636,9( \pm 19,9)$ & \\
\hline Median & 630 & 410 & 630 & \\
\hline Min-max & $300-670$ & $300-660$ & $610-670$ & \\
\hline $\begin{array}{l}\text { Diameter vena } \\
\text { pasca operasi } \\
(\mathrm{mm})\end{array}$ & & & & \\
\hline Mean $( \pm$ SD) & $5,6( \pm 1,2)$ & $4,2( \pm 1,1)$ & $6,3( \pm 0,2)$ & \\
\hline Median & 6,2 & 4,3 & 6,3 & \\
\hline Min-max & $2,4-6,7$ & $2,4-6,0$ & $6,0-6,7$ & \\
\hline $\begin{array}{l}\text { Kedalaman vena } \\
\text { pasca operasi } \\
(\mathrm{mm})\end{array}$ & & & & \\
\hline Mean $( \pm \mathrm{SD})$ & $5,6( \pm 0,5)$ & $5,7( \pm 0,8)$ & $5,5( \pm 0,3)$ & \\
\hline Median & 5,6 & 6,2 & 5,5 & \\
\hline Min-max & $4,5-6,3$ & $4,5-6,3$ & $4,8-6,0$ & \\
\hline
\end{tabular}




\section{ARTIKEL PENELITIAN}

*Uji Pearson

Tabel 2 Perbandingan Kadar CRP Serum Preoperatif Berdasarkan Maturasi AVF

\begin{tabular}{lccc}
\hline & $\begin{array}{c}\text { Non Matur } \\
\mathbf{n}=\mathbf{8}(\mathbf{3 3}, \mathbf{3} \%)\end{array}$ & $\begin{array}{c}\text { Matur } \\
\mathbf{n}=\mathbf{1 6}(\mathbf{6 6 , 7 \%})\end{array}$ & $\mathbf{p}^{*}$ \\
\hline $\begin{array}{l}\text { CRP serum preoperatif } \\
(\mathbf{m g} / \mathbf{d L})\end{array}$ & & & \\
$\quad$ Mean $( \pm$ SD) & $3,091( \pm 1,802)$ & $0,716( \pm 0,474)$ & 0,007 \\
Median & 3,050 & 0,567 & \\
Min-max & $0,882-6,030$ & $0,143-1,587$ & \\
\hline
\end{tabular}

* Uji t independent

Tabel 3 Hasil Analisis Regresi Logistik Bivariat

\begin{tabular}{lccccc}
\hline & $\begin{array}{c}\text { Non Matur } \\
\mathbf{n = 8}(\mathbf{3 3 , 3 \%})\end{array}$ & $\begin{array}{c}\text { Matur } \\
\mathbf{n}=\mathbf{1 6}(\mathbf{6 6 , 7 \%})\end{array}$ & $\mathbf{p}^{*}$ & $\mathbf{B}^{*}$ & $\mathbf{r 2}^{*}$ \\
\hline $\begin{array}{l}\text { CRP serum } \\
\text { preoperatif } \\
(\mathbf{m g} / \mathbf{d L})\end{array}$ & & & & & \\
$\quad$ Mean $( \pm$ SD) & $3,091( \pm 1,802)$ & $0,716( \pm 0,474)$ & 0,0285 & $-2,873$ & 0,711 \\
$\quad$ Median & 3,050 & 0,567 & & & \\
$\quad$ Min-max & $0,882-6,030$ & $0,143-1,587$ & & & \\
\hline * uji wald & & & & &
\end{tabular}




\section{Pasien GGT yang direncanakan untuk dibuat AVF}

- Informed consent

- Dilakukan pengambilan sampel CRP serum, beserta pemeriksaan preoperatif lainnva

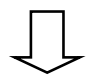

Dilakukan Operasi fistula Radiosefalika

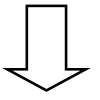

Dilakukan evaluasi fistula yang dibuat setelah 4 minggu

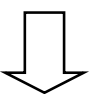

Pengukuran volume aliran darah, diameter, dan kedalaman vena sefalika dengan Doppler Ultrasonography GE Logiq C5 Premium pada vena sefalika yaitu $5 \mathrm{~cm}$ dari anastomosis oleh seorang dokter subspesialis bedah vaskular. Hasil dicatat.

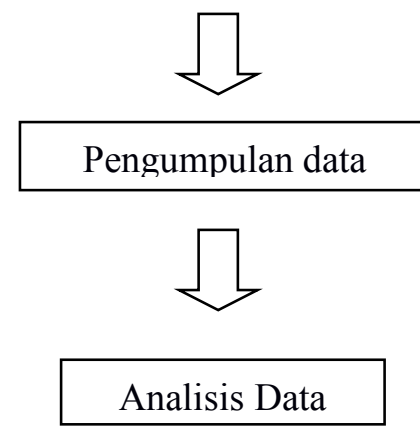

Gambar 1. Alur Penelitian. 